\title{
Blue-green infrastructure as a new trend and an effective tool for water management in urban areas
}

\begin{abstract}
Blue-green infrastructures (BGI) integrate solutions implemented to enhance water management and landscape values for more climateresilient and livable cities. BGI have created an opportunity to renew the natural structure of water balance in cities through the increase in rainwater retention and enlargement of permeable areas. The review of the literature on BGI development and solutions showed that the most popular BGI elements in terms of urban water quantity and quality were rain gardens, green roofs, vertical greening systems, and permeable pavements. Their structure and effectiveness were presented and reviewed. Despite the consensus between researchers that BGI benefit urban hydrology, differences in runoff decreased (2\%-100\%) lowering the peak flows (7\%-70\%) and infiltration (to $60 \%$ ) or evapotranspiration (19\%-84\%) were reported. Due to an individual technical structure, each BGI element plays a specific role and there is no universal BGI solution against water-related problems. We inferred that the most effective ones were individually adapted solutions, which prevent from a stressor. The greater variety of solutions in a given area, the more benefits for the urban environment. Our analyses showed that a holistic and co-creative approach to create blue-green networks should be considered in modern water management plans.
\end{abstract}

\author{
Ewelina Pochodyła ${ }^{1 *}$, Katarzyna \\ Glińska-Lewczuk ${ }^{1}$, Agnieszka \\ Jaszczak $^{2}$ \\ 1) University of Warmia and Mazury \\ in Olsztyn, Department of Water \\ Management and Climatology, \\ Olsztyn, Poland \\ 2) University of Warmia and \\ Mazury in Olsztyn, Department of \\ Landscape Architecture, Olsztyn, \\ Poland \\ *Corresponding author: Ewelina \\ Pochodyła, University of Warmia \\ and Mazury in Olsztyn, Department \\ of Water Management and \\ Climatology, Plac Łódzki 2, 10-719 \\ Olsztyn, Poland, Email: ewelina. \\ pochodyla@uwm.edu.pl
}

\section{Keywords:}

Blue-green infrastructure, Sustainable development, Climate change, Urban ecology, Rainwater management 


\section{Introduction}

The expansion of urban areas has resulted in an increased number of impervious surfaces, such as roads, parking lots, rooftops, and a decrease in the amounts of forested lands, wetlands, and other forms of open space that absorb and clean storm water naturally. Increasing urbanisation has limited permeable soil covers, natural vegetation, and the undisturbed hydrological cycle (McGrane 2016; Szewrański et al. 2018). Highly impermeable surfaces and climate change cause that cities to struggle with various extreme hydrometeorological phenomena (Baryła et al. 2019), including extremely high air temperatures (Perkins et al. 2012), urban droughts (Zhang et al. 2019b), floods, and local flooding (Kim et al. 2017).

Impervious surfaces are considered as an alternate measure for the cumulative impact of urbanisation on water resources without considering specific factors. Imperviousness leads to the alteration of the water balance; the water balance changes as the impermeable surfaces increase (Figure 1). In cities where grey infrastructures are the main component of space, the possibility of direct water infiltration is low. It has been reported (Zevenbergen et al. 2011) that in cities with $75-100 \%$ of impermeable cover, only about $10 \%$ of the rainfall could infiltrate the ground, mostly as shallow infiltration. As a result, water mainly $(60 \%)$ runs off on impermeable surfaces, washing out all impurities with it. The remaining amount of water evaporates (30\%). This disruption of the hydrological cycle in urbanised areas accelerates the rainwater runoff to watercourses (Wałęga et al. 2013).

Impervious surfaces collect pathogens, heavy metals, sediments, and chemical pollutants and quickly transmit these to streams, rivers, estuaries, or the sea downstream during rain. Due to limited natural infiltration, pollutants of urban origin are not naturally purified and surface runoff is so abundant that sewage systems cannot pre-treat water. As a result, this non-point source pollution is one of the major threats to water quality (Li and Davis 2009).

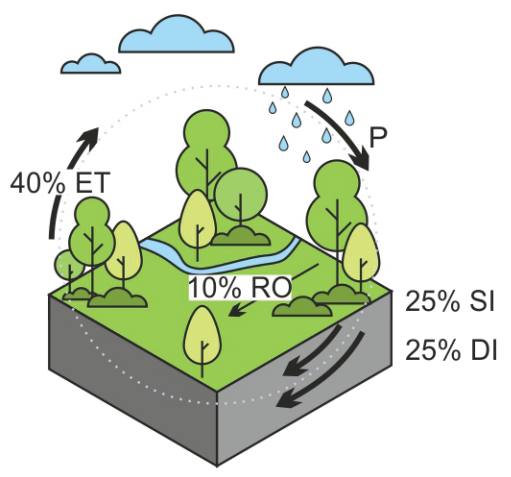

NATURAL GROUND COVER

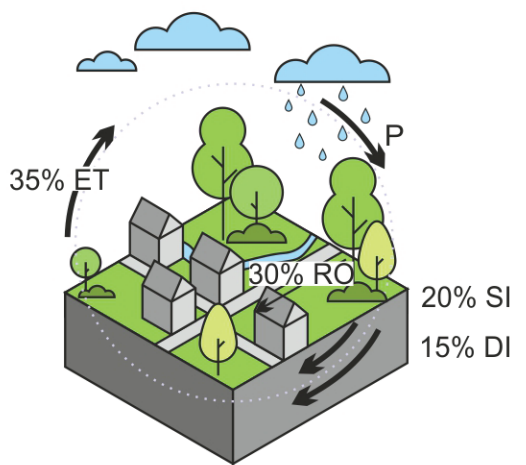

35-50\% IMPERVIOUS SURFACE

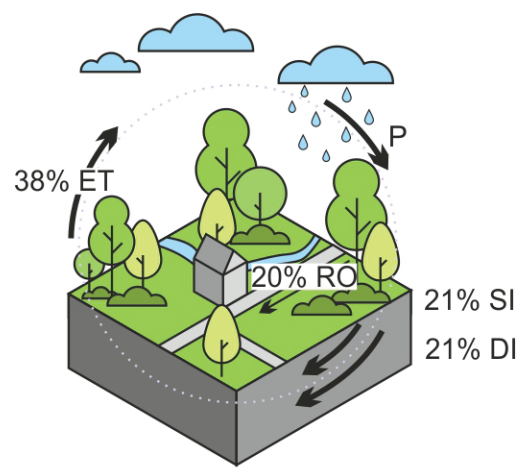

10-20\% IMPERVIOUS SURFACE

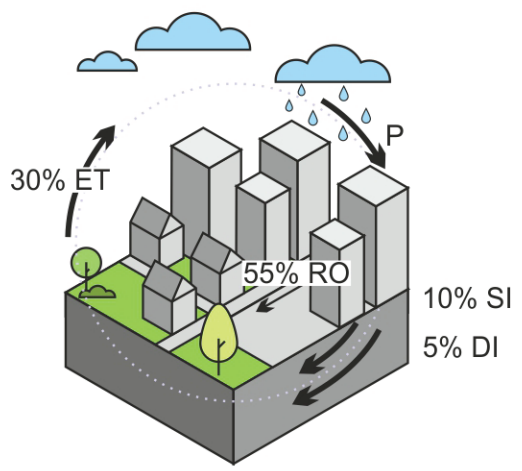

75-100\% IMPERVIOUS SURFACE
Denotations:

$P$ - precipitation, RO - runoff,

SI - shallow infiltration,

DI - deep infiltration,

ET - evapotranspiration

Figure 1. Changes in the structure of the water balance. Modified from Zevenbergen et al. (2011), Credit Valley Conservation (2015). 
Nature-based solutions (NBSs) are a multidisciplinary concept that combines social benefits with nature (Sowińska-Świerkosz et al. 2021). In view of the growing need for sustainable rainwater management in urban areas and the promotion of NBSs used for shaping urban spaces in recent years, the concepts of urban ecology and the protection of city residents have been developing intensively. Based on the European Commission report on NBS (2015), it should be indicated that these solutions, thanks to the use of existing natural elements, improve of biodiversity of ecosystems, while blue-green infrastructure (BGI) uses innovative solutions based on engineering structures. Both concepts follow the benefits created by nature. This explains why both NBS and BGI started to be used interchangeably (Nesshöver et al. 2017). The synonyms are used in reference to review studies (e.g. Ferreira et al. 2020), conceptual papers (e.g. Nesshöver et al. 2017) and case studies (e.g. Keesstra et al.2018).

The assumptions of $\mathrm{BGI}$ are related to common roots: vegetation-based urban design called green infrastructure $(\mathrm{Gl})$ and water-based solutions known as blue-infrastructures (BI). The term $\mathrm{GI}$ was used for the first time by Little (1990) in the 'Greenways for America'. Currently, there are many definitions of GI, while the most common is the definition provided by Benedict and McMahon (2002) and by the European Communication (2013). According to Benedict and McMahon (2002), Gl is understood as a network of related natural areas and other open spaces, preserving the natural values and functions of ecosystems, maintaining a clean air and water, and providing many benefits to people and the environment. According to the European Commission, in a report entitled 'Green Infrastructure - Increasing Europe's Natural Capital' (2013), GI was defined as a strate-

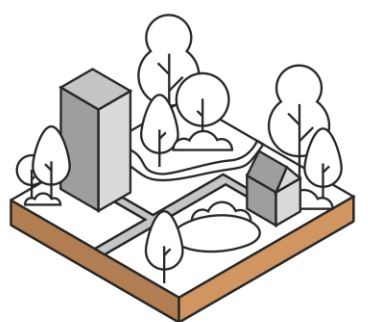

GREY INFRASTRUCTURE

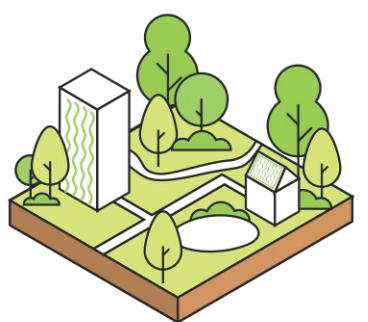

GREEN INFRASTRUCTURE

gically planned network of natural and semi-natural areas with other environmental features, which has been designed and managed to provide a various ecosystem services. It is expected to cover green areas (or blue for the water biosphere), as well as other physical features of land, coastal, and marine spaces. BI combines aquatic ecosystems or hydraulic infrastructures existing in the landscape. BI includes both small water reservoirs such as ponds, wetlands, rivers, lakes, streams, as well as larger reservoirs, including estuaries, seas, and oceans (Fritz 2017a). Similarly to green areas, water systems may create an interconnected hydrological network. An integral element of green urban spaces that enriches recreational and ecological functions is a "blue belt" around a city such as London or Brussels (Ioja et al. 2018).

The solutions based on green and blue infrastructures have become a basis for the concept of BGI. Under this meaning, BGI includes several natural (such as: rivers, ponds, wetlands) and designed landscape elements (such as: rain gardens, absorbent wells, underground systems), which provide ecological, landscape, economic, social, and environmental benefits (Ghofrani et al. 2016; Brears 2018; Ghofrani et al. 2020). Voskamp and van de Ven (2015) stated that by combining green and blue infrastructures into one element - BGI (Figure 2), it is possible to use its unique potential at various levels of spatial planning, enhancing urban water and climate conditions.

The BGI concept has evolved over several centuries. The first mentions that ideologically correspond to the concept of BGI are dated back to 1850 (Benedict and McMahon 2002) and come from the United States. The milestones in the development of the BGI concept are the following: the creation of The Emerald Necklace in 1896, combining parks and parkways

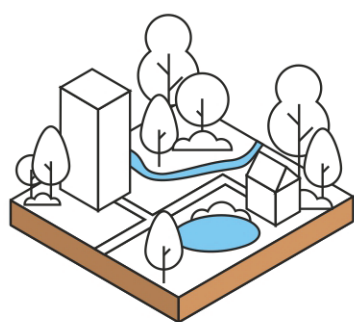

BLUE INFRASTRUCTURE

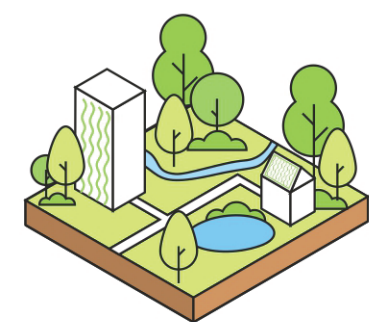

BLUE-GREEN INFRASTRUCTURE

Figure 2. Blue-green infrastructure idea. Source: own elaboration of authors. 
in Boston, USA (Kusuluoglu and Aytac 2016); Ebenezer Howard's 'Garden City' theory (Howard 1898); the establishment of National Park system in the US (1901-1909); the creation of the Bronx river parkway, the first boulevard designed for motorists in harmony with nature (Davis 2007); the 'Green Belt' concept (Elson 1986); and the introduction of the terms 'ecology' (Clements 1916), 'landscape ecology' (Naveh and Lieberman 1990), and 'conservation biology' (Pullin 2002). Since the 1990s, interest in $\mathrm{BGI}$ issues, planning, and design in accordance with the principles of ecology has increased significantly. Moreover, society has become more aware of the value of urban landscapes, management, and the need to protect ecological networks (Benedict and McMahon 2002).

The term "infrastructure" in BGI indicates that the role of natural processes involving vegetation or water features is essential in providing a variety of services to urban residents. The $\mathrm{GI}$ and $\mathrm{BI}$ in $\mathrm{BGI}$ are a significant enhancement of the GI idea. It should be noted that the proper functioning of plant elements depends on water resources. Simultaneously, vegetation determines the activity of local hydrological processes (Dreiseitl and Wanschura 2016).

The approach presented in this work focuses on the concept of BGI, which combines the green, blue, and ecosystem network issues. The use of the term BGI allows for the presentation of more flexible ecological solutions. BGI, in addition to green and blue elements and processes, also includes engineering elements such as permeable pavements, rain gardens, and soakaways (Ahmed et al. 2019).

This paper aims to present a review of recent literature on the concepts and solutions about four types of BGI (rain gardens, green roofs, vertical greening systems, and permeable pavements) supporting sustainable water management in urban areas. Based on the literature review, the following research questions were formulated: (i) what is the role of $\mathrm{BG}$ lelements in water management in urban areas? (ii) Which of BGI elements is the most effective tool supporting urban water management? The presented review on functionalities and benefits of four BGI elements provides material for discussions on securing clean and sufficient freshwater as a challenge for cities in the 21 st century.

\section{Methods}

\subsection{Literature search}

The analysis of BGI literature (Xiao and Watson 2019) comprised an extended search of keywords in two online databases (Web of Science Core Collection and Google Scholar): "blue and green infrastructure", "rain garden", "vertical greenery system", "permeable pavement", "green roof", "nature based solution", and the above keywords with details such as: "... and water management", "... and climate", "... and landscape", "... and benefits", "... and noise". The search results for each term were rated based on the article or book title. If it was appropriate to the research, a full record was saved for further relevance assessment (Figure 3). The source selection was limited to the period from 1999 to 2020. At first, Google Scholar was used. After reviewing the first 10 pages of search results for each keyword, 103 potentially relevant articles were collected. In the Web of Science Core Collection database 148 articles were selected. In addition in both databases, through searching by authors, backward searching and forward searching, another 40 studies were identified. From the 291 articles found during the selection procedure depicted in Figure 2, 156 full-text papers were screened. The final number of studies included 128 items, which were classified thematically into five categories: "BGI-general information and history", "Characteristic elements of BGI", "BGI and climate change", "BGI in water management", and "BGI and the landscape and society". The collected information was systematised in the context of the functions and benefits provided by each BGI element. The database was supplemented with a document of the European Commission 'Green Infrastructure - Increasing Europe's Natural Capital' (2013) which concerns the BGI issues. To further analyse data compiled identifying the characteristics of BGI elements, types of solutions, technical structure, role in rainwater management, impact on water quality, role in improving the landscape, and the quality of life of residents. 


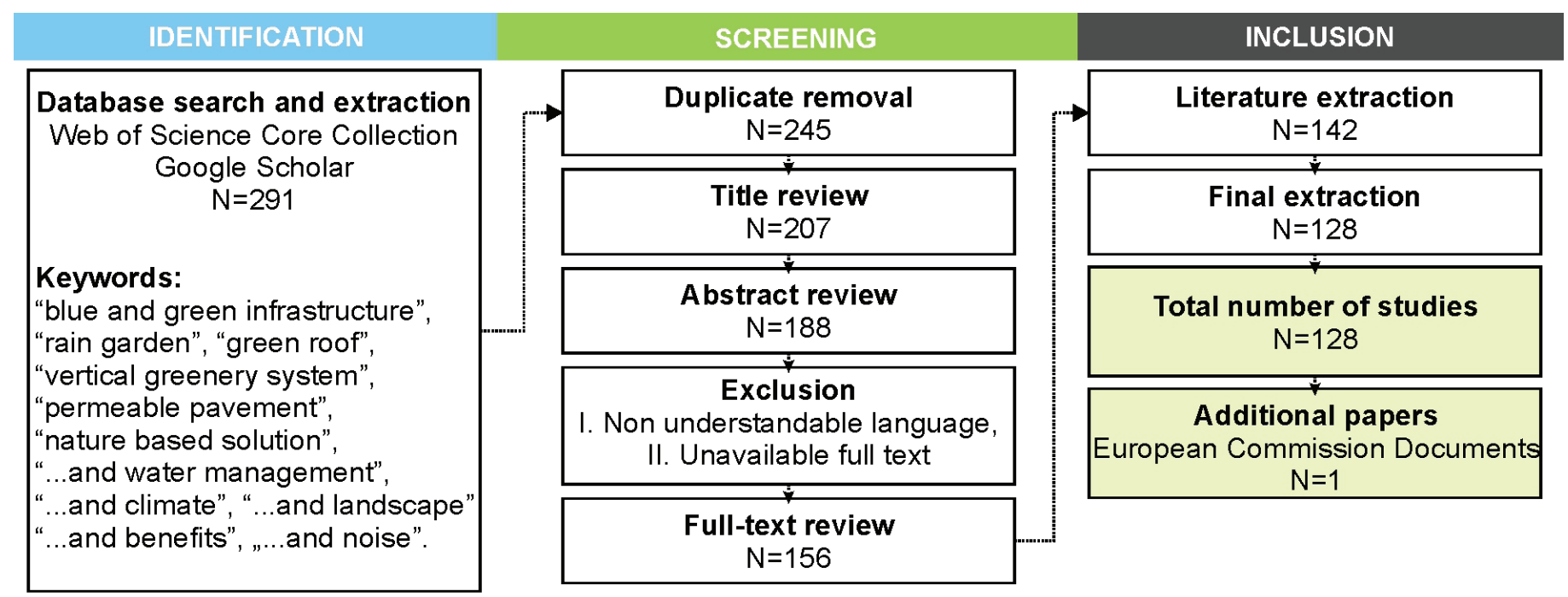

Figure 3. Procedure of literature search and selection applied in this study. Source: own study.

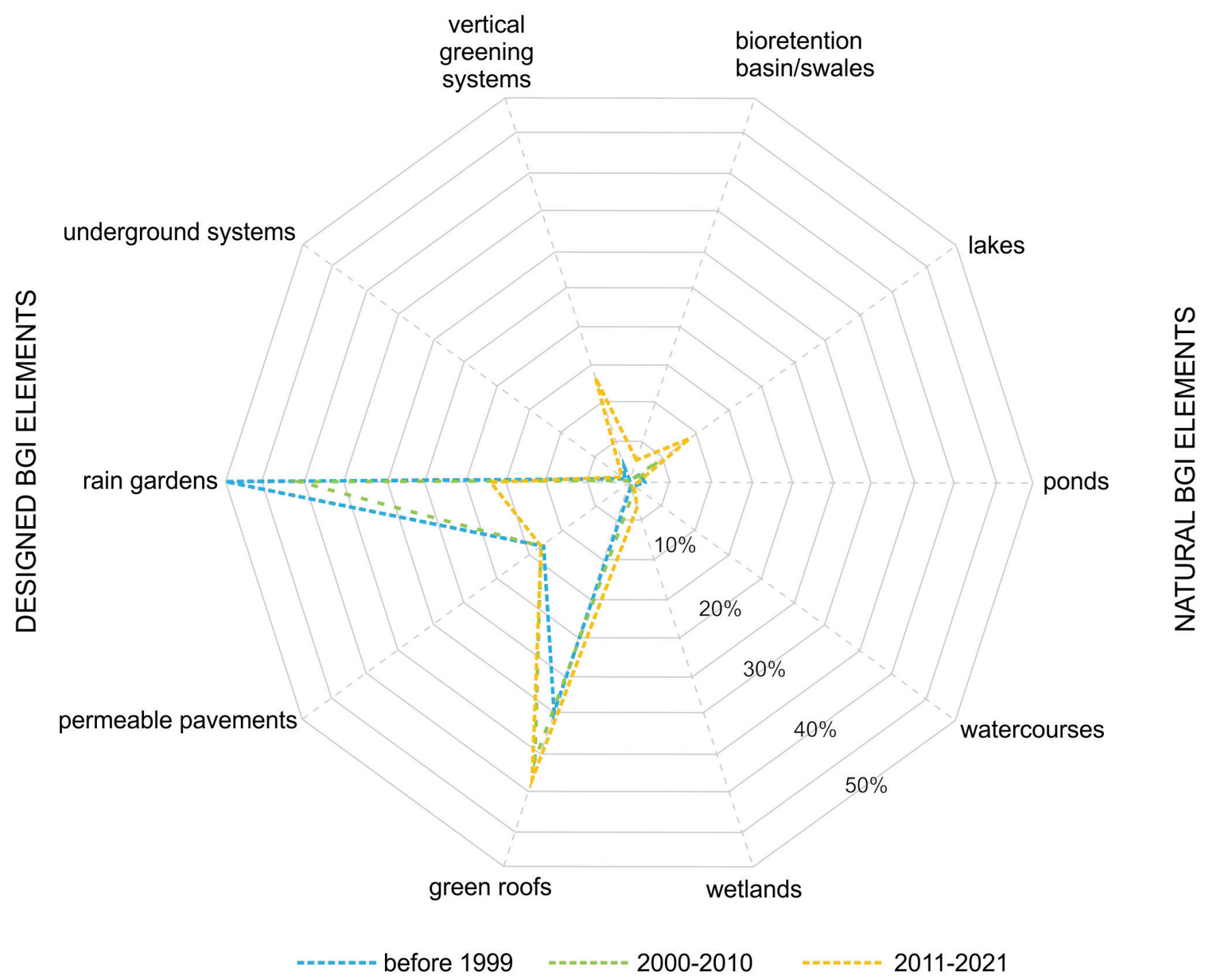

Figure 4. The share (\%) of publications on selected BGI elements. Source: own study based on Web of Science Core Collection database. 


\subsection{Selection criteria of BGI elements}

The analysis of literature database comprised both technical and natural elements of BGI. To show temporal changes in popularity of the subject the results were divided into three time-span categories: publications issued before 1999, in 2000-2010, and 2011-2021. The first category was the period before the US report on the BGI concept (1999). The subsequent categories were the following ten-year intervals to assess the trends at the turn of the last decades. In each category, the shares of publications were defined concerning (among others): bioretention basins/swales, lakes, ponds, watercourses, wetlands, rain gardens, green roofs, vertical greening systems (VGS), permeable pavements, and underground constructions.

BGI have often been reported as a remedy for urban areas, where natural water cycling is disrupted e.g., through the limited permeability of the ground. Considering this, the BGI as an effective tool for urban water management has attracted many scientists who have presented both technical (48) and hydrometeorological (71) approaches. Quantitative analysis of literature on BGI showed rain gardens as the most popular subject of publications both before 1999 and in the period from 2000-2010 (41, and $50 \%$, respectively) (Figure 4). In the period from 2011-2021 the highest interest (38\%) met green roofs. Besides, from various man-made constructions, the highest popularity gained vertical greening systems and permeable pavements.

From various $\mathrm{BGI}$ solutions reported in the literature, the four most popular BGI elements were selected for detailed analyses: rain gardens, green roofs, VGS, and permeable pavements. According to Versini et al. (2018), these four elements were the most important and popular due to a number of benefits for urban spaces. The description of each solution comprised a definition, types, and classification criteria. The importance of each element was presented in the relation to its role for water management.

\section{Results and discussion}

\subsection{Blue-green infrastructure elements in urban areas}

As a result of the literature analysis, it was found that a coherent vision of the BGI concept, that has attracted much research attention in recent years. The resources of the Web of Science (June 8, 2021) showed that the concepts of $\mathrm{GI}, \mathrm{BI}$, and $\mathrm{BGI}$ have been gradually gaining popularity in the literature since ca. 2000, which correlates with a US report (1999) indicating that BGI is one of the key strategies for sustainable development. The first references to GI appeared in 1995, and about BI in 2006, while the first publication about BGI was made relatively late, as it was published in 2013 by Rozos et al. According to the Web of Science - Core Collection database, until June 2021 the number of publications was as follows: 3,568 publications about $\mathrm{GI}, 130$ about $\mathrm{BI}$, and 92 about BGI. The year of 2020 had the most abundant papers on $\mathrm{GI}, \mathrm{BI}$, and $\mathrm{BGI}$, when 687,25 , and 31 were published, respectively. From three research concepts, comparing the number of publications before 2019 and those published later, the highest increase in interest showed a BGI of $+59 \%$. Most works were devoted to the role of BGI in mitigating climate change or urbanisation.

Among the various solutions of $\mathrm{BGI}$, emphasise would be given to four elements, which combine knowledge of hydrological and hydrodynamic processes, and design solutions used in water management systems: rain gardens, green roofs, vertical greening systems, and permeable pavements. Below provide their characteristics, types and features that enable effective support for water management in the cities. It should be noted that their potential results from the possibility of installation in a dispersed manner, tailored to the individual characteristics of a given area.

\subsection{Rain gardens}

Rain gardens are also called bioretention/bioinfiltration cells (DelVecchio et al. 2020) or biological retention pools ( $\mathrm{Li}$ et al. 2018). They are created in natural or formed depressions in landscapes (Zou et 
al. 2018). The location of such facilities is of strategic importance, which is why they are most often placed near storm sewers (Siwiec et al. 2018). Yuan et al. (2017) recommended locating them alongside roads, sidewalks, or buildings as these gardens have the ability to effectively retain rainwater. The construction of a rain garden has a complex structure (Figure 5). A layer of gravel requires their placement on properly prepared soil (Zou et al. 2018) and the substrate should be covered with a mulch layer. The upper layer consists of carefully selected plant species (Muthanna et al. 2008), which allows the maintenance of the rain garden in a visually attractive form and makes it a fully functional object. According to Ishimatsu et al. (2017), due to the natural capacity to absorb and store water by the soil-plant system, rain gardens are supposed to be self-sufficient in irrigation and fertilisation. Perennials and shrubs used in rain gardens adapt to local climatic conditions and are resistant to periodic flooding and droughts (Yuan and Dunnet 2018).

Three moisture zones in rain gardens can be distinguished both vertically and horizontally (Figure 5). A central part of the rain garden, with the largest depression and the highest soil moisture, is its base. The slope of the rain garden is an area with moderate soil moisture. Usually, decreasing moisture gradient towards the edge of the garden is observed. The margin of the garden usually has the highest location (Yuan and Dunnett 2018).
Rain gardens are primarily used to mitigate the effects of excessive rainfall by collecting and treating rainwater. It is estimated that rain gardens retain about $30 \%$ more water in the ground than lawns (Siwiec et al. 2018). They improve water retention, which is of great importance in mitigating the effects of climate change (e.g. urban heat islands) through increased air humidity and temperatures decreased by $10^{\circ} \mathrm{C}$ (Zou et al. 2018; Iwaszuk et al. 2019). According to Ebrahimian et al. (2019), the evapotranspiration rate ranging from $19-84 \%$ tended to be most significant in rain gardens. Many authors have agreed that rain gardens reduce rainwater runoff, however, reported rates vary from $1.93-42 \%$ of the total (Yang et al. 2009; Li et al. 2018).

\subsection{Green roofs}

Green roofs are carefully selected layer systems that provide suitable conditions for growing plants (Pęczkowski et al. 2016). The green roof layers (Figure 6) include, above all, a waterproof membrane, root barrier, drainage layer, substrate, and plant elements such as perennials, shrubs, and bushes (Saadatian et al. 2013). Selected plants also limit the choice of substrate (Baryła et al. 2018) and its depth (Shafique et al. 2018). They may be treated as compensation for vegetation destroyed during the building's construction (Rowe 2011).

Green roofs have been divided into three main types (Figure 6) according to the type of plants used and,

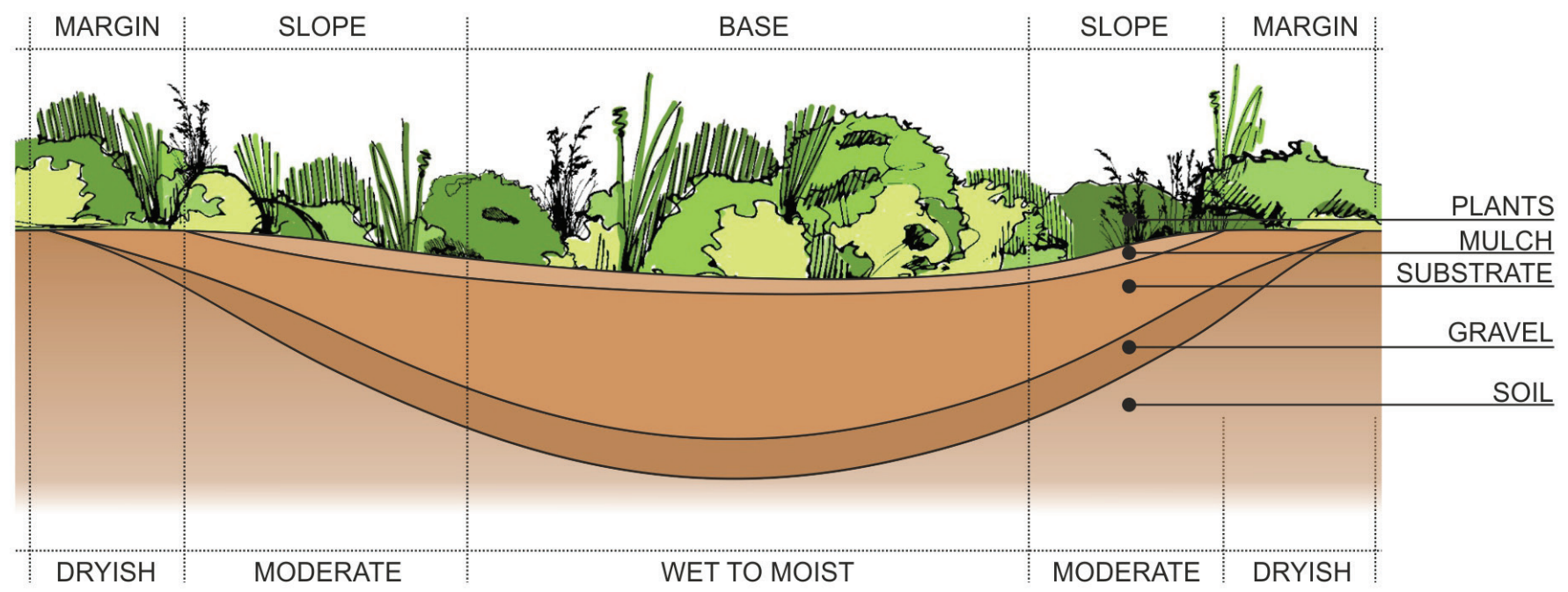

Figure 5. Layers and moisture zones of a rain garden. Modified from Yuan and Dunnet (2018). 
as a consequence, the thickness of the substrate layers: intensive, semi-intensive, and extensive (Besir and Cuce 2018).

Intensive green roofs, due to the variety of plants and advanced structures, require constant and laborious maintenance. Such roofs are spaces that can be open to the public are intended for recreational use. However, due to high costs, they have been built mainly on residential buildings, hotels, and underground parking lots (Rowe 2011, Saadatian et al. 2013). Due to the thickest layer of the substrate, diverse vegetation, including a variety of trees, shrubs, and perennials, can be used here. To avoid the risk of damage to the roof construction by plant root systems, a root barrier layer is usually installed (Shafique et al. 2018). Intensive green roofs are suitable for placing various technical infrastructure elements on them, such as solar panels. This type of roof garden significantly loads the roof compared to the other types. The total height of these layers is $150-400 \mathrm{~mm}$, and the weight is $180-500 \mathrm{~kg} / \mathrm{m}^{2}$ (Besir and Cuce 2018).

Semi-intense roofs require a moderate thickness of the plant substrate, mainly in the form of digestive plants, herbs, and shrubs (Vacek et al. 2017). The thickness of this system is $120-250 \mathrm{~mm}$, and its weight is $120-200 \mathrm{~kg} / \mathrm{m}^{2}$. They are mainly used to improve the aesthetic value of spaces (Besir and Cuce 2018). Therefore, they are installed in exposed places, and, thanks to their relatively low weight, they can even be used on renovated roofs (Vacek et al. 2017).

Extensive green roofs are often installed on steep roofs and places where access is restricted or denied to the public. It is the lightest green roof construction $\left(60-150 \mathrm{~kg} / \mathrm{m}^{2}\right)$ with a total height of $60-200 \mathrm{~mm}$ (Besir and Cuce 2018). The substrate layer here is the thinnest among the green roof types, which requires plats with a shallow root system, which grow slowly, although they spread quickly. Therefore, on this type of roof mosses, herbs, sedum, and grasses are preferred. Although the number of species suitable for this type of roof is lower, their biodiversity is usually greater than that of intensive roofs (Rowe 2011).

Green roofs have been reported to be one of the most effective in terms of rainwater storage or retardation. Rainwater retention on a green roof depends on the annual rainfall, air temperature, climate, and plant selection (Getter et al. 2007; Liu et al. 2019). Roof parameters such as slope gradient and slope length affect infiltration, runoff, and total flow. As the gradient of the slope increases, infiltration decreases, and runoff increases. In contrast, lengthening the slope increases infiltration and reduces runoff and total flow (Cai et al. 2020). The water outflow from the green roof undergoes the same processes as in natural systems: part of the rainfall is captured by the vegetation layer, while part of it infiltrates into the deeper layers where it is stored; the remaining part undergoes evaporation and transpiration pro-

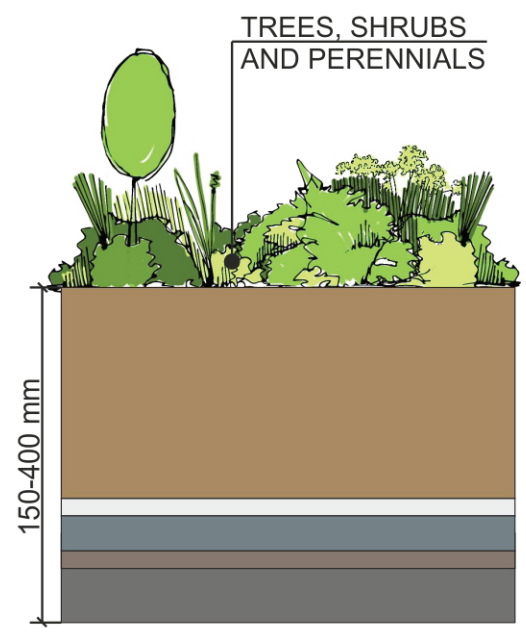

INTENSIVE GREEN ROOF

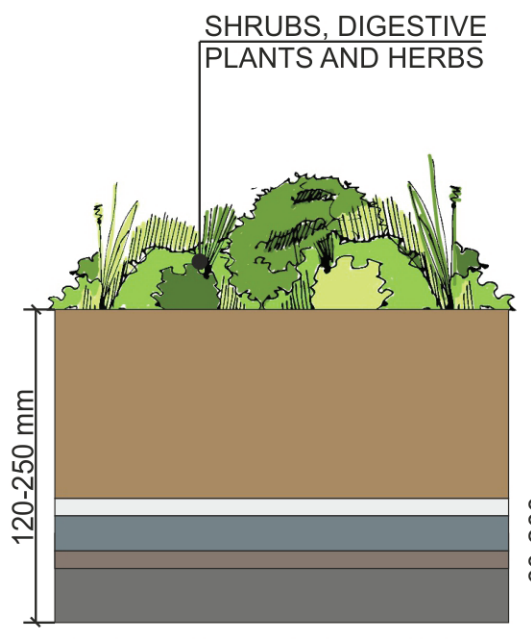

SEMI-INTENSIVE GREEN ROOF

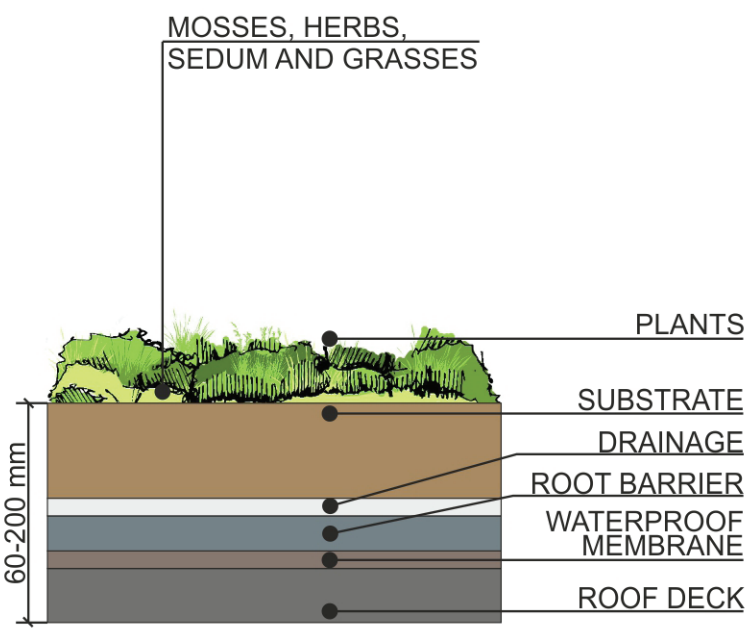

EXTENSIVE GREEN ROOF

Figure 6. Schematics of green roof constructions. Modified from Saadatian et al. (2013), Besir and Cuce (2018). 
cesses (30-86\% of rainfall) (Ebrahimian et al. 2019). As a result, green roofs reduce surface runoff by $2-100 \%$, depending on the depth of the substrate and the plants used; the deeper layer of the substrate provide better results than a standard roof by about 5-69\% (Soulis et al. 2017; Li et al. 2019).

\subsection{Vertical greening systems}

Vertical greening systems (VGS) are living vertical gardens that are self-sufficient (Perez et al. 2017). They are based on various construction systems, depending on a type of vertical garden (Coma et al. 2017). The structures are attached to the external or internal walls of the building (Radic et al. 2019). They may occupy entire walls, although smaller empty spaces can also be converted into vegetated walls (Perez et al. 2017).

The number of plant species suitable for such constructions is much smaller than the number of species that can be used on green roofs (Perez et al. 2017; Radic et al. 2019). Most often, VGS are divided according to the growing method into two main types: living walls (green walls) and green façades (Figure 7) (Coma et al. 2017; Radic et al. 2019).

Living walls (green walls) are called 'double skin green facades' (Perez et al. 2017) because the plants are placed and rooted on these with a technical design. The entire technical installation is mounted on the wall of the building (Radic et al. 2019). Living walls are made of panel modules. Each module is filled with a substrate that allows plants to grow properly. The modules use, for example, soil, foam, and perlite. There are four types of living walls according to their base: planter boxes made of HDPE, felt layers, foam substrate, and mineral wool layers. Living walls are filled by perennials, herbs, grasses, or small shrubs which do not naturally grow vertically (Perini and Ottelé 2014). Plants in construction brackets draw water and nutrients from this level without direct contact with the ground level (Radic et al. 2019).

Green façades are called 'traditional green facades' since the walls are covered with climbing vegetation, and one plant species or compound of species often dominates. In this type of VGS, the plants uptake water and nutrients directly from the soil because they are rooted there (Perez et al. 2017). Creepers can be placed directly on a building's wall or on additional constructions such as cables or nets (Koch et al. 2020). Supporting structures can be made of various materials, with the most popular being steel, wood, plastic, and aluminium (Perini and Ottelé 2014).

VGS have been reported in the literature as having a positive effect on urban hydrology by improving the water cycle. They retain $45-75 \%$ of rainfall (Kew et al. 2014; Lau and Mah 2018). The retained water can be used to irrigate these installations. Despite this,

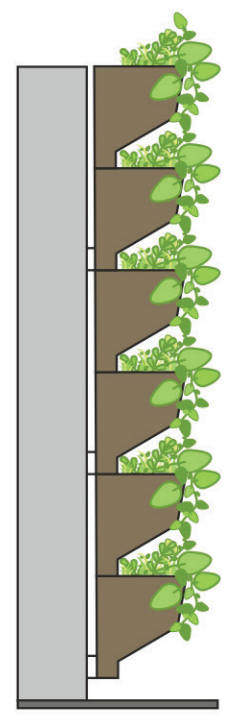

A. Living wall on planter boxes

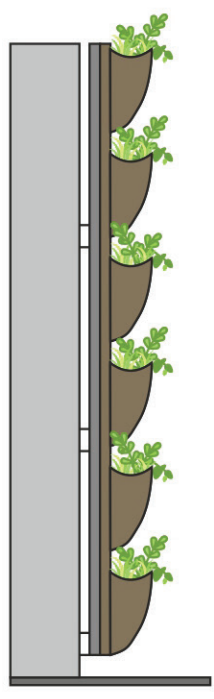

B. Living wall on felt layers

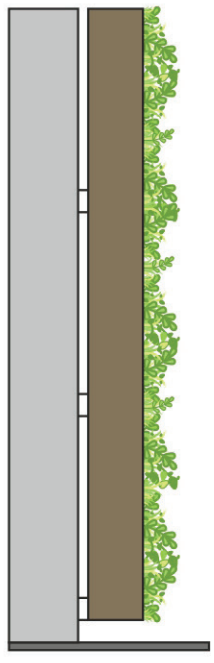

C. Living wall on foam substrate
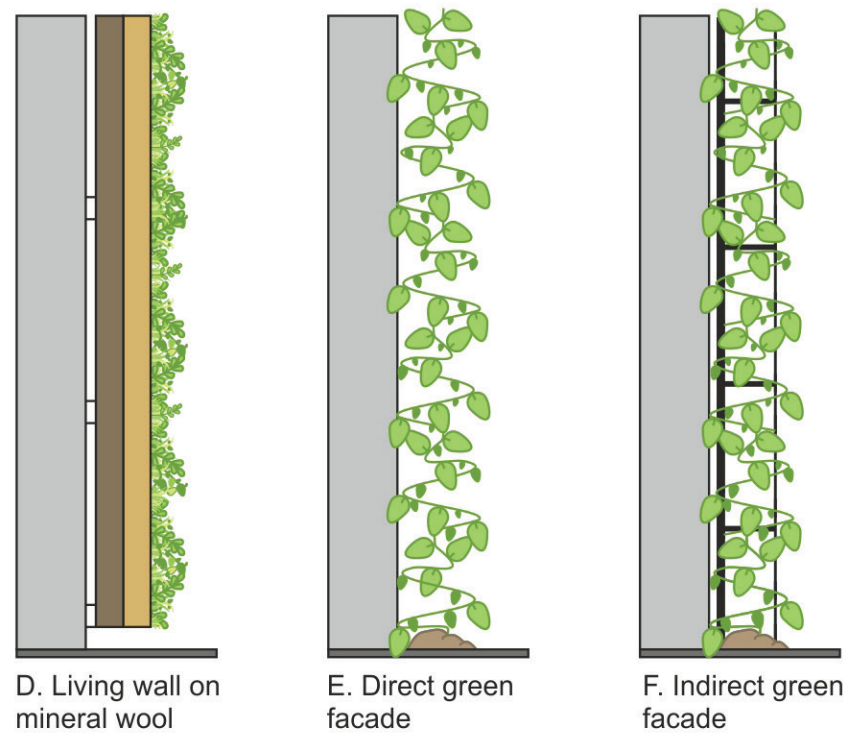

Figure 7. Types of Vertical Greening Systems. Modified from Perini and Ottelé (2014). 
they require an additional irrigation system, which is necessary during periods of water deficits. Due to high losses of water through evapotranspiration (ca. $23 \%$ ), local storm sewer systems are not overloaded, which is important for urban areas (Van de Wouw et al. 2017; Lau and Mah 2018).

VGS have been reported to reduce rainwater runoff by $4-87 \%$, depending on the type of substrate and the duration and intensity of precipitation (Lau and Mah 2018; Radic et al. 2019). The research by Lau and Mah (2018) indicated that, considering only the type of substrate, sand was the most effective in reducing surface runoff (55.1\%) The other assessed substrates, i.e. loamy sand, sandy loam, and loam, obtained similar results (54.6-54.8\%).

\subsection{Permeable pavements}

Permeable pavements are an alternative solution for impermeable surfaces used in residential, commercial, and industrial areas, for parking, roads, or pedestrian paths, especially where the traffic is low (Sanicola et al. 2018; Sun et al. 2018). This is an effective way to improve hydrological and ecological properties in urban areas (Sanicola et al. 2018; Lu et al. 2020). Permeable pavements have been reported to perform four hydrological functions: storage of rainwater, reduction of surface runoff, outflow delay, and the delay of peak outflow (Fassman and Blackbourn 2010; Lin et al. 2014).

The construction of permeable pavement consists of four layers (Figure 8). The subgrade layer, namely the existing soil being covered by a base layer made of open-graded aggregates. Right above it, there is the bedding layer, whilst the top layer is made of paving material (Scholz and Grabowiecki 2007; Lin et al. 2014; Saadeh et al. 2019). Permeable pavements can consist of various materials, characterised by high porosity and a void-rich structure so that rainwater can freely infiltrate through the layers. According to the literature, the most suitable materials include porous asphalt, porous cement, permeable interlocking concrete pavement, or advanced polyurethane mixtures (Sun et al. 2018; Lu et al. 2020).

Three main types of permeable pavements are distinguished in Figure 8: a permeable pavement surface, a semi-permeable pavement, and a fully permeable pavement (Lin et al. 2014; Sun et al. 2018; Lu et al. 2020). The division is related to the permeability rate in the pavement structure. The permeable pavement surface does not allow water to infiltrate the substrate. This type of construction keeps the water in the pavement structure. The semi-permeable surface allows for the partial infiltration of water into the substrate, but most of it is stored in the pavement structure. In constructions of this type, the top layer is made of highly porous materials and the lower layers are impermeable. The full permeable pavement enables the complete infiltration of rainwater into the substrate and further down into the groundwater.

Permeable pavements are an important element of BGI due to their better than impervious surfaces infiltration conditions (from 130 to several thousand $\mathrm{mm} / \mathrm{h}$ ) resulting in an increase in groundwater re-

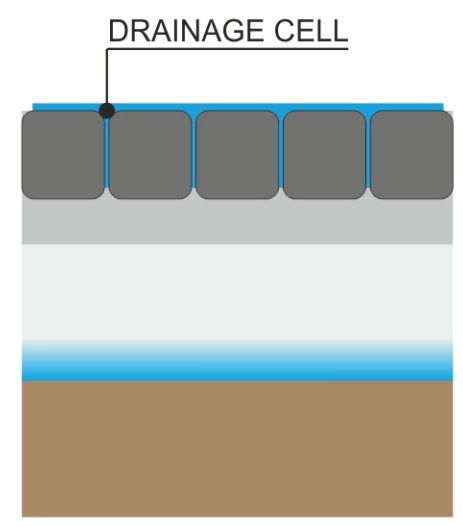

FULLY PERMEABLE PAVEMENT

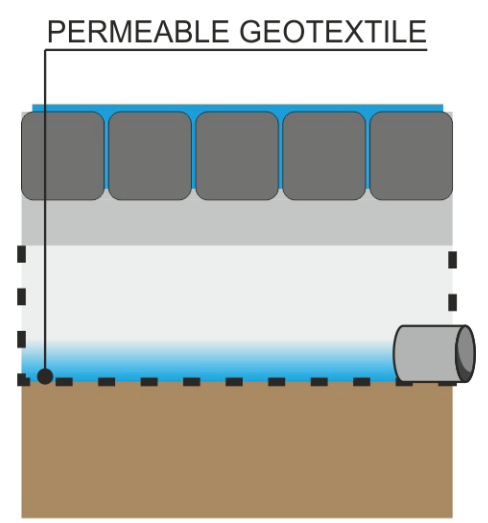

SEMI-PERMEABLE PAVEMENT

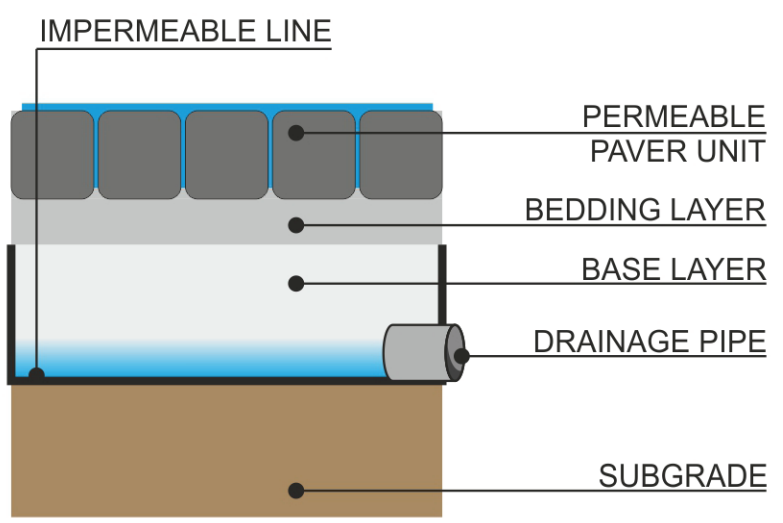

PERMEABLE PAVEMENT SURFACE

Figure 8. Types of permeable pavements. Modified from Scholz and Grabowiecki (2007), Lu et al. (2020). 
sources (Sanicola et al. 2018). Along with the infiltration process, rainwater undergoes purification (see section 3.6, Table 1). Otherwise, it would supply the storm water system, and thus surface water recipients (watercourses and lakes). It has been reported that the permeable pavement retention of water during rainfall reduces the total outflow to $20 \%$, thus limiting the risk of flooding. Moreover, due to the restored soil permeability, the role of the subsurface component of the hydrological cycle is increasing. This part of the water cycle is getting longer (Lin et al. 2014; Sanicola et al. 2018; Sun et al. 2018). Permeable pavements also affect the atmospheric phase (evaporation) of water. They lower not only the surface temperature of the pavement by $6.7-9.4^{\circ} \mathrm{C}$ but also the ambient temperature by $0.2-1.8^{\circ} \mathrm{C}$, which contributes to the reduction of the phenomenon called an urban heat island (Lin et al. 2013; Liu et al. 2018).

\subsection{Benefits of BGI elements for urban water}

$\mathrm{BGI}$, due to the multifunctionality and possibility to integrating solutions (Fritz 2017b), provides several benefits. Usually, the benefits from various fields occur simultaneously, and regardless of the environment, the number of BGI elements, and the size of the area within their reach. However, sometimes, one effect can exclude others (Andrew 2017).

Since BGI is a combination of engineering elements with soil-plant components, cities at risk of flooding gain new possibilities to manage surface runoff during such weather events, which leads directly to a lower risk of flooding (Fritz 2017b; Morakinyo et al. 2017). This has been attributed to plants and soils, which are able to store large amounts of water (Shafique et al. 2018). BGI elements, thanks to their specificity, also effectively improve rainfall infiltration (Francis and Jensen 2017). This is particularly important, for example, in bringing the groundwater to the right level (Brears 2018).

BGI has beneficial effects on rainwater management and water quality. However, the literature review showed that these solutions contribute to the improvement of the structure of urban water balance to a different degree. According to the literature listed in Table 1, the highest effectiveness reaches up to $100 \%$, while rainwater reduction reaches $86 \%$.
Rain gardens have been reported to show the highest potential in the peak flow reduction (by $70 \%$ ). Rain gardens also appear to be a primary solution for improving infiltration rates (up to $60 \%$ ). A wide range of results from the studies on evapotranspiration from BGI was reported: from $19-84 \%$ of rainfall for rain gardens, from $51.5-83 \%$ for green roofs, and $23 \%$ for VGS.

BGI elements effectively absorb contaminants from rivers, lakes, and other water reservoirs, and directly from the rainwater contributing to its purification. They are capable of removing a range of heavy metals (i.e., $\mathrm{Cu}, \mathrm{Cd}, \mathrm{Pb}, \mathrm{Zn}, \mathrm{Cr}$ ) by ca. $80-90 \%$, phosphorus by ca. $65 \%$, and total suspended solids by ca. $90 \%$. It has also been reported that BGI significantly reduces the risk of erosion and sedimentation (Brears 2018; Shafique et al. 2018).

\subsection{Landscape and social effects of BGI in cities}

The implementation of BGI elements to urban spaces due to their water-related benefits also has other positive effects, particularly for the quality of life of residents, for the landscape, and aesthetic values. By transforming some areas with impermeable properties into green areas, the public is given relief from ubiquitous concrete, which improves their mental and physical health (Shafique et al. 2018). Unlimited access to natural elements leads to an increase in life satisfaction and increase in productivity, which often affects success in professional life and reduces the risk of illness (Fritz 2017b). Plants can absorb noise, which in cities is a stress factor (Abhijith et al. 2017; Fritz 2017b; Morakinyo et al. 2017). According to Peck and Kuhn (2001) the use of BGI can reduce noise levels by up to $40 \mathrm{~dB}$. BGI elements make the space greener, more attractive, and improve the aesthetics of buildings and entire cities (Andrew 2017; Morakinyo et al. 2017). Moreover, well-maintained and frequently used spaces can also limit the crime rates in these areas (Brears 2018). Using BGI for the improvement of aesthetics and the creation of unique places, which groups of people can enjoy, strongly favours the integration of society; residents more eagerly engage in local activities to improve social cohesion and develop local attachments to the place (Shafique et al. 2018). 
Table 1. Summary of the effects of blue-green infrastructures based on the available literature.

\begin{tabular}{|c|c|c|c|}
\hline BGI Elements & Effect & Results & Reference \\
\hline \multirow[t]{15}{*}{ Rain gardens } & \multirow{7}{*}{$\begin{array}{l}\text { Rainwater } \\
\text { management }\end{array}$} & Runoff reduction by $42 \%$ & Yang et al. (2009) \\
\hline & & Runoff reduction by $12.7-19.4 \%$ & Autixier et al. (2014) \\
\hline & & Runoff reduction by $1.93-9.69 \%$ & Li et al. (2018) \\
\hline & & Peak flow reduction by $70 \%$ & Yang et al. (2009) \\
\hline & & Peak flow reduction by $7-56 \%$ & Autixier et al. (2014) \\
\hline & & Infiltration: $60 \%$ & Zhang et al. (2019a) \\
\hline & & Evapotranspiration: $19-84 \%$ & Ebrahimian et al. (2019) \\
\hline & \multirow{8}{*}{$\begin{array}{l}\text { Improving } \\
\text { water quality }\end{array}$} & Heavy metals reduction: $90 \%$ of $\mathrm{Cu}, \mathrm{Pb}, \mathrm{Zn}$ & \multirow[t]{4}{*}{ Dietz and Clausen (2005) } \\
\hline & & TKN reduction by $68 \%$ & \\
\hline & & $\mathrm{N}(\mathrm{NH} 3-\mathrm{N})$ reduction by $87 \%$ & \\
\hline & & NO3-N reduction by $24 \%$ & \\
\hline & & Heavy metals reduction: $80-90 \%$ of $\mathrm{Cu}, \mathrm{Zn}, \mathrm{Cd}, \mathrm{Pb}$ & \multirow[t]{4}{*}{ Siwiec et al. (2018) } \\
\hline & & PAHs reduction by $70-90 \%$ & \\
\hline & & Phosphate reduction by $63 \%$ & \\
\hline & & Particles reduction by $90 \%$ & \\
\hline \multirow{12}{*}{$\begin{array}{l}\text { Green roofs } \\
\text { E-extensive, } \\
\text { SI-semi-in- } \\
\text { tensive, } \\
\text { I-intensive. }\end{array}$} & \multirow{7}{*}{$\begin{array}{l}\text { Rainwater } \\
\text { management }\end{array}$} & Runoff reduction $50-100 \%$ & Rowe (2011) \\
\hline & & Runoff reduction $2-100 \%$ & Soulis et al. (2017) \\
\hline & & Runoff reduction $40-80 \%$ & Xing and Jones (2019) \\
\hline & & Runoff reduction $5-69 \%$ compared to standard roofs & Li et al. (2019) \\
\hline & & Evapotranspiration: $51.5 \%$ & Besir and Cuce (2018) \\
\hline & & (E) Evapotranspiration: 83\% & \multirow[t]{2}{*}{ Ebrahimian et al. (2019) } \\
\hline & & Retention of rainfall: $30-86 \%$ & \\
\hline & \multirow[t]{5}{*}{$\begin{array}{l}\text { Improving } \\
\text { water quality }\end{array}$} & $\begin{array}{l}\text { (SI) Heavy metals reduction: } 99 \% \text { of } \mathrm{Pb}, 99 \% \text { of } \mathrm{Zn}, 99 \% \text { of } \mathrm{Cu}, 98 \% \\
\text { of } \mathrm{Cd} \text { (summer) }\end{array}$ & \multirow[t]{5}{*}{ Berndtsson (2010) } \\
\hline & & $\begin{array}{l}\text { (SI) Heavy metals reduction: } 68 \% \text { of } \mathrm{Cu}, 2 \% \text { of } \mathrm{Zn}, 88 \% \text { of } \mathrm{Cd}, 94 \% \\
\text { of } \mathrm{Pb} \text { (winter) }\end{array}$ & \\
\hline & & $\begin{array}{l}\text { (E) Heavy metals reduction: } 97 \% \text { of } \mathrm{Cu}, 96 \% \text { of } \mathrm{Zn}, 92 \% \text { of } \mathrm{Cd}, 99 \% \\
\text { of } \mathrm{Pb} \text { (summer) }\end{array}$ & \\
\hline & & $\begin{array}{l}\text { (E) Heavy metals reduction: } 44 \% \text { of } \mathrm{Cu}, 72 \% \text { of } \mathrm{Zn}, 62 \% \text { of } \mathrm{Cd}, 91 \% \\
\text { of } \mathrm{Pb} \text { (winter) }\end{array}$ & \\
\hline & & $\begin{array}{l}\text { Heavy metals reduction: } 61 \% \text { of } \mathrm{Cr}, 24 \% \text { of } \mathrm{Mn}, 93 \% \text { of } \mathrm{Pb}, 8 \% \\
\text { of } \mathrm{Zn} \text { (loads in precipitation }=100 \% \text { ) }\end{array}$ & \\
\hline \multirow[t]{5}{*}{ VGSs } & \multirow{5}{*}{$\begin{array}{l}\text { Rainwater } \\
\text { management }\end{array}$} & Runoff reduction $20-87 \%$ & Lau and Mah (2018) \\
\hline & & Runoff reduction $4 \%$ & Radic et al. (2019) \\
\hline & & Retention of rainfall: $45-75 \%$ & Kew et al. (2014) \\
\hline & & Retention of rainfall: $45-75 \%$ & Lau and Mah (2018) \\
\hline & & Evapotranspiration: $23 \%$ & Van de Wouw et al. (2017) \\
\hline \multirow{4}{*}{$\begin{array}{l}\text { Permeable } \\
\text { pavements }\end{array}$} & \multirow{4}{*}{$\begin{array}{l}\text { Rainwater } \\
\text { management }\end{array}$} & Runoff reduction $1-40 \%$ & Hu et al. (2018) \\
\hline & & Peak flow reduction by $42.9-57.2 \%$ & Lin et al. (2014) \\
\hline & & Peak flow reduction by $7-43 \%$ & Hu et al. (2018) \\
\hline & & Total outflow reduction by $10-20 \%$ & Lin et al. (2014) \\
\hline
\end{tabular}




\begin{tabular}{|c|c|c|c|}
\hline \multirow[t]{7}{*}{$\begin{array}{l}\text { Permeable } \\
\text { pavements }\end{array}$} & \multirow[t]{7}{*}{$\begin{array}{l}\text { Improving } \\
\text { water quality }\end{array}$} & Heavy metals reduction: $84 \%$ of $\mathrm{Pb} ; 77 \%$ of $\mathrm{Cd} ; 73 \%$ of $\mathrm{Zn}$ & $\begin{array}{l}\text { Legret and Colandini } \\
\text { (1999) }\end{array}$ \\
\hline & & Heavy metals reduction: $99 \%$ of $\mathrm{Zn}$ & \multirow[t]{3}{*}{ Winer (2000) } \\
\hline & & TSS reduction by $82-95 \%$ & \\
\hline & & TP reduction by $65 \%$ & \\
\hline & & TSS reduction by $79.8-98.6 \%$ & \multirow[t]{3}{*}{ Niu et al. (2016) } \\
\hline & & COD reduction by $9 \%$ & \\
\hline & & TP reduction by $74.2 \%$ & \\
\hline
\end{tabular}

It is worth mentioning that the effects of introducing more modern green elements and complementing existing green spaces improves a region's image. BGI significantly improves recreational and tourist conditions in cities, as it provides public spaces that have been improved for its users (Andrew 2017). Thanks to this, entrepreneurs willingly invest and develop companies in these areas (Shafique et al. 2018) which favours the development of tourism and recreation. These areas can be used to promote wildlife and encourage the introduction of nature into cities (Shafique et al. 2018). On the long-term perspective, a city may also gain local distinctiveness against the background of larger administrative units (Landscape Institute 2013). Even the creation of places for urban agriculture thanks to BGI can make a society self-sufficient (Shafique et al. 2018). As a result, the city can create local spaces for food production, which can also be used in educational activities for children and youths in the field of food production, on their own and the life cycle of plants (Brears 2018).

The relatively wide range of costs of $B G I, 10-2800 € /$ $\mathrm{m}^{2}$, depending on the element (Perini and Rosasco 2013; Liberalesso et al. 2020), may be a barrier for city residents. Consequently, states and cities are introducing incentive policies to encourage residents to make this type of investment. Most often, cities offer subsidies (53\% in a global context), obligations by law $(15 \%)$, tax breaks $(10 \%)$, or storm water fee discounts $(6 \%)$ in return for placing a BGI element (Liberalesso et al. 2020).

\section{Conclusions}

The relatively new concept of $\mathrm{BGI}$ is gaining increasing interest from scientists and stakeholders who can see multiple benefits for urban areas as panacea for water-related problems or solutions for the improvement of the quality of life of residents as well as the landscape, and aesthetic values. It results from an ample of advantages performed by BGI, which, besides having relatively low unit costs, relies on its diversity, dispersion, and relatively small areas, which allow for its adaptation to the limited urban space, existing infrastructures, as well as local hydrometeorological conditions.

The presented literature review shows consistency about the enhancing role of a BGI in the hydrology of urban areas. Nevertheless, each of the BGI elements, due to its unique technical structure, size, location, and plants used, plays specific roles. None of the solutions from the group of four elements - rain gardens, green roofs, VGSs, and permeable pavements - which are reported to have the greatest potential in the field of water management, can be judged as fully universal. Since green roofs seem to be the most effective in reducing runoff by $100 \%$ and increasing retention by $86 \%$, for technical reasons, they are not foreseen to significantly enhance the infiltration of water throughout the ground, for example. This attribute (as well as a peak flow reduction) belongs to permeable pavements or rain gardens with an effectiveness estimated at a level of $60 \%$.

In view of this, when cities suffer from unproductive and quick runoff, washing out a load of pollutants, or undergo local and periodic flooding, it is particularly important to provide them with adequate solutions. The most effective were "tailor-made" solutions, which respond to a stressor or a group of stressors. The greater the variety of solutions in an area, the more hydrological, landscape, and social benefits for the urban environment. 
Bearing in mind that "small is beautiful and effective" there is still a need to assess cumulative effects that bring $\mathrm{BGI}$. This requires a general approach on a watershed scale. To assess the overall hydrological efficiency of BGI solutions, they should be however assessed on the scale of an urban watershed, according to the rules of the EU Water Framework Directive (2000/60/WE). Two basic factors need to be analysed: the complexity of solutions in a selected area (density) and the diversity of technical-biological solutions adapted to local hydro-meteorological conditions.

Due to the intensive development of urban spaces, BGI provides several tools that support the urban space management system in an effective, impressive, and pro-social way. The results of BGI solutions functioning in cities show that this trend in urban planning has value not only for landscapes but it is also a long-term effective tool for water management in cities. Up-to-date experiences with implementations various types of $B G I$ positively influencing the hydrological aspects in cities show that a holistic and co-creative approach to create blue-green networks should be considered in modern water management plans.

\section{Acknowledgements}

The results presented in this paper were obtained as part of a comprehensive study financed by the University of Warmia and Mazury in Olsztyn, Faculty of Agriculture and Forestry, Department of Water Management and Climatology (grant No. 30.610.008110).

Project financially supported by Minister of Science and Higher Education in the range of the program entitled "Regional Initiative of Excellence" for the years 2019-2022, Project No. 010/RID/2018/19, amount of funding 12.000.000 PLN.

\section{References}

Abhijith, K. V., Kumar, P., Gallagher, J., McNabola, A., Baldauf, R., Pilla, F., Broderick, B., Di Sabatino, S., Pulvirenti, B. 2017. Air pollution abatement performances of green infrastructure in open road and built-up street canyon environments A review. Atmospheric Environment 162, 71-86. DOI:10.1016/j.atmosenv.2017.05.014

Ahmed, S., Meenar, M., Alam, A. 2019. Designing a Blue-Green Infrastructure (BGI) Network: Toward Water-Sensitive Urban Growth Planning in Dhaka, Bangladesh. Land, 8(9). DOI:10.3390/ land8090138

Andrew, R. F. 2017. Spatial Evaluation of Multiple Benefits to Encourage Multi-Functional Design of Sustainable Drainage in Blue-Green Cities. Water 9(12), 953. DOI:10.3390/w9120953

Autixier, L., Mailhot, A., Bolduc, S., Madoux-Humery, A. S., Galarneau, M., Prevost, M., Dorner, S. 2014. Evaluating rain gardens as a method to reduce the impact of sewer overflows in sources of drinking water. Science of the Total Environment 499, 238247. DOI:10.1016/j.scitotenv.2014.08.030

Baryła, A., Gnatowski, T., Karczmarczyk, A., Szatyłowicz, J. 2019. Changes in Temperature and Moisture Content of an Extensive-Type Green Roof. Sustainability 11(9), 2498. DOI:10.3390/ su11092498

Baryła, A., Karczmarczyk, A., Brandyk, A., Bus, A. 2018. The influence of a green roof drainage layer on retention capacity and leakage quality. Water Science and Technology 77(12), 2886-2895. DOI:10.2166/wst.2018.283

Benedict, M. A., McMahon, E. T. 2002. Green Infrastructure: Smart Conservation for the 21st Century. Sprawl Watch Clearinghouse Monograph Series, Washington

Berndtsson, J. C. 2010. Green roof performance towards management of runoff water quantity and quality: A review. Ecological Engineering 36(4), 351-360. DOI:10.1016/j.ecoleng.2009.12.014 
Besir, A. B., Cuce, E. 2018. Green roofs and facades: A comprehensive review. Renewable \& Sustainable Energy Reviews 82, 915-939. DOI:10.1016/j. rser.2017.09.106

Brears, R.C. 2018. Blue and Green Cities. The role of Blue-Green infrastructure in managing urban water resources. Macmillan Publishers Ltd, London.

Cai, W. L., Huang, H., Chen, P. N., Huang, X. L., Gaurav, S., Pan, Z., Lin, P. 2020. Effects of biochar from invasive weed on soil erosion under varying compaction and slope conditions: comprehensive study using flume experiments. Biomass Conversion and Biorefinery. DOI:10.1007/s13399020-00943-3

Clements, F. E. 1916. Plant succession: An analysis of the development of vegetation. Carnegie Institution of Washington Publication 242. DC: Carnegie Institution of Washington, Washington. DOI:10.5962/bhl.title.56234

Coma, J., Perez, G., de Gracia, A., Bures, S., Urrestarazu, M., Cabeza, L. F. 2017. Vertical greenery systems for energy savings in buildings: A comparative study between green walls and green facades. Building and Environment 111, 228-237. DOI:10.1016/j.buildenv.2016.11.014

Credit Valley Conservation (CVC). 2015. Lessons Learned: CVC Stormwater Management and Low Impact Development Monitoring and Performance Assessment Guide. https://cvc. ca/wp-content/uploads/2016/06/Monitoring_ Guide_Final.pdf [Accessed 27 November 2020].

Davis, T. 2007. The Bronx River Parkway and photography as an instrument of landscape reform. Studies in the History of Gardens \& Designed Landscapes 27(2), 113-141. DOI:10.108 0/14601176.2007.10435461

DelVecchio, T., Welker, A., Wadzuk, B. M. 2020. Exploration of Volume Reduction via Infiltration and Evapotranspiration for Different Soil Types in Rain Garden Lysimeters. Journal of Sustainable Water in the Built Environment 6(1), 04019008. DOI:10.1061/jswbay.0000894
Dietz, M. E. 2007. Low impact development practices: A review of current research and recommendations for future directions. Water Air and Soil Pollution 186(1-4), 351-363. DOI:10.1007/ s11270-007-9484-z

Dietz, M. E., Clausen, J. C. 2005. A field evaluation of rain garden flow and pollutant treatment. Water Air and Soil Pollution 167(1-4), 123-138. DOI:10.1007/s11270-005-8266-8

Dunnett, N., Kingsbury, N. 2004. Planting green roofs and living walls, Timber Press Inc., Portland.

Dreiseitl, H., Wanschura, B. 2016. Strengthening Blue-Green Infrastructure in our Cities: Enhancing Blue-Green Infrastructure \& Social Performance in High-Density Urban Environments. Ramboll Foundation. https://ramboll.com/-/ media/38fc23d12a5d47dcb7b382 1716d69270. pdf [Accessed 8 August 2021].

Ebrahimian, A., Wadzuk, B., Traver, R. 2019. Evapotranspiration in green stormwater infrastructure systems. Science of the Total Environment, 688, 797-810. DOI:10.1016/j. scitotenv.2019.06.256

European Commission 2013. Building a Green Green Infrastructure for Europe. Publications Office of the European Union, Luxembourg. https:// ec.europa.eu/environment/nature/ecosystems/ docs/green_infrastructure_broc.pdf [Accessed 9 February 2020].

European Commission 2015. Towards an EU Research and Innovation Policy Agenda for Nature-Based Solutions and Re-Naturing Cities; European Commission: Brussels, Belgium. https://ec.europa.eu/programmes/horizon2020/ en/news/towards-eu-research-and-innovationpolicy-agenda-nature-based-solutions-renaturing-cities [Accessed 8 August 2021].

Fassman, E. A., Blackbourn, S. 2010. Urban Runoff Mitigation by a Permeable Pavement System over Impermeable Soils. Journal of Hydrologic Engineering 15(6), 475-485. DOI:10.1061/(asce) he.1943-5584.0000238

Ferreira, V., Barreira, A. P., Loures, L., Antunes, D., Panagopoulos, T. 2020. Stakeholders' 
Engagement on Nature-Based Solutions: A Systematic Literature Review. Sustainability 12(2). DOI:10.3390/su12020640

Francis, L. F. M., Jensen, M. B. 2017. Benefits of green roofs: A systematic review of the evidence for three ecosystem services. Urban Forestry \& Urban Greening 28, 167-176. DOI:10.1016/j. ufug.2017.10.015

Fritz, M. 2017a. Integrating the Grey, Green, and Blue in Cities: Nature-Based Solutions for Climate Change Adaptation and Risk Reduction. In: Kabisch, N., Korn, H., Stadler, J., Bonn, A. (eds.), Nature-Based Solutions to Climate Change Adaptation in Urban Areas: Linkages between Science, Policy and Practice. Springer, Cham, pp. 91-109.

Fritz, M. 2017b. Nature-Based Solutions and Buildings - The Power of Surfaces to Help Cities Adapt to Climate Change and to Deliver Biodiversity. In: Kabisch, N., Korn, H., Stadler, J., Bonn, A. (eds.), Nature-Based Solutions to Climate Change Adaptation in Urban Areas: Linkages between Science, Policy and Practice. Springer, Cham, pp. 159-183.

Getter, K. L., Rowe, D. B., Andresen, J. A. 2007. Quantifying the effect of slope on extensive green roof stormwater retention. Ecological Engineering 31(4), 225-231. DOI:10.1016/j. ecoleng.2007.06.004

Ghofrani, Z., Sposito, V., Faggian, R. 2016. Designing resilient regions by applying Blue- Green Infrastructure concepts. Sustainable City Xi 204, 493-505. DOI:10.2495/SC160421

Ghofrani, Z., Sposito, V., Faggian, R. 2020. Maximising the Value of Natural Capital in a Changing Climate Through the Integration of Blue-Green Infrastructure. Journal of Sustainable Development of Energy Water and Environment Systems-Jsdewes 8(1), 213-234. DOI:10.13044/j. sdewes.d7.0279

Howard, E. 1898. To-morrow: A Peaceful Path to Real Reform. Swan Sonnenschein \& Co., Ltd, London

Hu, M. C., Zhang, X. Q., Siu, Y. L., Li, Y., Tanaka, K., Yang, H., Xu, Y. P. 2018. Flood Mitigation by Permeable
Pavements in Chinese Sponge City Construction. Water 10(2), 172. DOI:10.3390/w10020172

Ioja, I. C., Osaci-Costache, G., Breuste, J., Hossu, C. A., Gradinaru, S. R., Onose, D. A., Nita, M. R., Skokanova, H. 2018. Integrating urban blue and green areas based on historical evidence. Urban Forestry \& Urban Greening 34, 217-225. DOI:10.1016/j.ufug.2018.07.001

Ishimatsu, K., Ito, K., Mitani, Y., Tanaka, Y., Sugahara, T., Naka, Y. 2017. Use of rain gardens for stormwater management in urban design and planning. Landscape and Ecological Engineering 13(1), 205-212. DOI:10.1007/s11355-016-0309-3

Iwaszuk, E., Rudik, G., Duin, L., Mederake, L., Davis, M., Naumann, S., Wagner, I. 2019. Addressing Climate Change in Cities - Catalogue of Urban Nature-Based Solutions. Ecologic Institute \& the Sendzimir Foundation, Berlin - Kraków

Keesstra, S., Nunes, J., Novara, A., Finger, D., Avelar, D., Kalantari, Z., Cerdà, A. 2018. The superior effect of nature based solutions in land management for enhancing ecosystem services. Science of the Total Environment 610, 997-1009. DOI:10.1016/j. scitotenv.2017.08.077

Kew, B., Pennypacker, E., Echols, S. 2014. Can greenwalls contribute to stormwater management? A study of cistern storage greenwall first flush capture. Journal of Green Building 9(3), 85-99. DOI:10.3992/1943-4618-9.3.85

Kim, Y., Eisenberg, D. A., Bondank, E. N., Chester, M. V., Mascaro, G., Underwood, B. S. 2017. Fail-safe and safe-to-fail adaptation: decision-making for urban flooding under climate change. Climatic Change 145(3-4), 397-412. DOI:10.1007/s10584017-2090-1

Koch, K., Ysebaert, T., Denys, S., Samson, R. 2020. Urban heat stress mitigation potential of green walls: A review. Urban Forestry \& Urban Greening 55, 126843. DOI:10.1016/j.ufug.2020.126843

Kusuluoglu, D. D., Aytac, G. 2016. Urban parks and their role on sustainable urban water cycle. Journal of Environmental Protection and Ecology 17(2), 621-628. 
Landscape Institute 2013. Green Infrastructure: An Integrated Approach to Land Use, Landscape Institute Policy Statement. https:// landscapewpstorage01.blob.core.windows. net/www-landscapeinstitute-org/2016/03/ GreenInfrastructureLIPositionStatement2013.pdf [Accessed 24 May 2020].

Lau, J. T., Mah, D. Y. S. 2018. Green Wall for Retention of Stormwater. Pertanika Journal of Science and Technology 26(1), 283-297

Legret, M., Colandini, V. 1999. Effects of a porous pavement with reservoir structure on runoff water: Water quality and fate of heavy metals. Water Science and Technology 39(2), 111-117. DOI:10.1016/s0273-1223(99)00014-1

Li, C. H., Peng, C., Chiang, P. C., Cai, Y. P., Wang, X., Yang, Z. F. 2019. Mechanisms and applications of green infrastructure practices for stormwater control: A review. Journal of Hydrology 568, 626637. DOI:10.1016/j.jhydrol.2018.10.074

Li, H., Davis, A. P. 2009. Water Quality Improvement through Reductions of Pollutant Loads Using Bioretention. Journal of Environmental Engineering 135(8), 567-576. DOI:10.1061/(asce) ee.1943-7870.0000026

Li, J. K., Zhang, B., Li, Y. J., Li, H. E. 2018. Simulation of Rain Garden Effects in Urbanized Area Based on Mike Flood. Water 10(7), 860. DOI:10.3390/ w10070860

Liberalesso, T., Cruz, C. O., Silva, C. M., Manso, M. 2020. Green infrastructure and public policies: An international review of green roofs and green walls incentives. Land Use Policy 96, 104693. DOI:10.1016/j.landusepol.2020.104693

Lin, J. D., Hsu, C. Y., Citraningrum, A., Adhitana, P. 2013. The Impact of Different Types of Permeable Pavement Utilization on Air Temperature above the Pavement. Innovation and Sustainable Technology in Road and Airfield Pavement 723, 678-685. DOI:10.4028/www.scientific.net/ AMR.723.678

Lin, W. G., Ryu, S., Cho, Y. H. 2014. A case study of flow characteristics of permeable pavements by time and space model. Canadian Journal of Civil
Engineering 41(7), 660-666. DOI:10.1139/cjce2013-0165

Little, Ch. 1990. Greenways for America. The Johns Hopkins University Press, Washington.

Liu, W., Feng, Q., Chen, W. P., Wei, W., Deo, R. C. 2019. The influence of structural factors on stormwater runoff retention of extensive green roofs: new evidence from scale-based models and real experiments. Journal of Hydrology 569, 230-238. DOI:10.1016/j.jhydrol.2018.11.066

Liu, Y., Li, T., Peng, H. Y. 2018. A new structure of permeable pavement formitigating urban heat island. Science of the Total Environment 634, 1119-1125. DOI:10.1016/j.scitotenv.2018.04.041

Lu, G. Y., Torzs, T., Liu, P. F., Zhang, Z. Y., Wang, D. W., Oeser, M., Grabe, J. 2020. Dynamic Response of Fully Permeable Pavements: Development of Pore Pressures under Different Modes of Loading. Journal of Materials in Civil Engineering 32(7), 04020160. DOI:10.1061/(asce)mt.19435533.0003217

McGrane, S. J. 2016. Impacts of urbanisation on hydrological and water quality dynamics, and urban water management: a review, Hydrological Sciences Journal-Journal Des Sciences Hydrologiques 61(13), 2295-2311. DOI:10.1080/ 02626667.2015.1128084

Morakinyo, T. E., Dahanayake, K., Ng, E., Chow, C. L. 2017. Temperature and cooling demand reduction by green-roof types in different climates and urban densities: A co-simulation parametric study. Energy and Buildings 145, 226237. DOI:10.1016/j.enbuild.2017.03.066

Muthanna, T. M., Viklander, M., Thorolfsson, S. T. 2008. Seasonal climatic effects on the hydrology of a rain garden. Hydrological Processes 22(11), 1640-1649. DOI:10.1002/hyp.6732

Naveh, Z., Lieberman, A.S. 1990. Landscape ecology: Theory and application. Springer-Verlag, New York

Nesshöver, C., Assmuth, T., Irvine, K. N., Rusch, G. M., Waylen, K. A., Delbaere, B., Haase, D., Jones-Walters, L., Keune, H., Kovacs, E., Krauze, K., Külvik, M., Rey, F., Van Dijk, J., Vinstad, O.D., 
Wilkinson, M. E., Wittmer, H. 2017. The science, policy and practice of nature-based solutions: An interdisciplinary perspective. Science of the Total Environment 579, 1215-1227. DOI:10.1016/j. scitotenv.2016.11.106

Niu,Z. G., Lv,Z.W.,Zhang, Y., Cui, Z.Z. 2016. Stormwater infiltration and surface runoff pollution reduction performance of permeable pavement layers. Environmental Science and Pollution Research 23(3), 2576-2587. DOI:10.1007/s11356-0155466-7

Peck, S., Kuhn, M. 2001. Design guidelines for green roofs. https://www.eugene-or.gov/ DocumentCenter/View/1049/Design-Guidelinesfor-Green-Roofs [Accessed 15 February 2020].

Perez, G., Coma, J., Sol, S., Cabeza, L. F. 2017. Green facade for energy savings in buildings: The influence of leaf area index and facade orientation on the shadow effect. Applied Energy 187, 424437. DOI:10.1016/j.apenergy.2016.11.055

Perini, K., Ottelé, M. 2014. Designing green façades and living wall systems for sustainable constructions. International Journal of Design \& Nature and Ecodynamics 9(1), 31-46. DOI:10.2495/dne-v9-n1-31-46

Perini, K., Rosasco, P. 2013. Cost-benefit analysis for green facades and living wall systems. Building and Environment 70, 110-121. DOI:10.1016/j. buildenv.2013.08.012

Perkins, S. E., Alexander, L. V., Nairn, J. R. 2012. Increasing frequency, intensity and duration of observed global heatwaves and warm spells. Geophysical Research Letters 39(20). DOI:10.1029/2012gl053361

Pęczkowski, G., Orzepowski, W., Pokładek, R., Kowalczyk, T., Żmuda, R., Wójcik, R. (2016). Retention properties of the type of extensive green roofs as an example of model tests. Acta Scientiarum Polonorum-Formatio Circumiectus 15(3), 113-120. DOI:10.15576/asp. fc/2016.15.3.113

Pullin, A. S. 2002. Conservation biology. Cambridge University Press, Cambridge DOI:10.1017/ CBO9781139051927
Radic, M., Dodig, M. B., Auer, T. 2019. Green Facades and Living Walls-A Review Establishing the Classification of Construction Types and Mapping the Benefits. Sustainability 11(17), 4579. DOI:10.3390/su11174579

Rowe, D. B. 2011. Green roofs as a means of pollution abatement. Environmental Pollution 159(8-9), 2100-2110. DOI:10.1016/j.envpol.2010.10.029

Rozos, E., Makropoulos, C., Maksimovic, C. 2013. Rethinking urban areas: an example of an integrated blue-green approach. Water Science and Technology-Water Supply, 13(6), 1534-1542. DOI:10.2166/ws.2013.140

Saadatian, O., Sopian, K., Salleh, E., Lim, C. H., Riffat, S., Saadatian, E., Toudeshki, A., Sulaiman, M. Y. 2013. A review of energy aspects of green roofs. Renewable \& Sustainable Energy Reviews 23, 155-168. DOI:10.1016/j.rser.2013.02.022

Saadeh, S., Ralla, A., Al-Zubi, Y., Wu, R., Harvey, J. 2019. Application of fully permeable pavements as a sustainable approach for mitigation of stormwater runoff. International Journal of Transportation Science and Technology 8(4), 338350. DOI:10.1016/j.ijtst.2019.02.001

Sanicola, O.,Lucke, T., Devine,J.2018.Usingpermeable pavements to reduce the environmental impacts of urbanisation. International Journal of Geomate 14(41), 159-166. DOI:10.21660/2018.41.Key3

Scholz, M., Grabowiecki, P. 2007. Review of permeable pavement systems. Building and Environment 42(11), 3830-3836. DOI:10.1016/j. buildenv.2006.11.016

Shafique, M., Kim, R., Rafiq, M. 2018. Green roof benefits, opportunities and challenges - A review. Renewable \& Sustainable Energy Reviews 90, 757-773. DOI:10.1016/j.rser.2018.04.006

Siwiec, E., Erlandsen, A. M., Vennemo, H. 2018. City Greening by Rain Gardens - Costs and Benefits. Environmental Protection and Natural Resources 29(1), 1-5. DOI:10.2478/oszn-2018-0001

Soulis, K. X., Ntoulas, N., Nektarios, P. A., Kargas, G. 2017. Runoff reduction from extensive green roofs having different substrate depth and plant cover. 
Ecological Engineering 102, 80-89. DOI:10.1016/j. ecoleng.2017.01.031

Sowińska-Świerkosz, B., Michalik-Śnieżek, M., \& Bieske-Matejak, A. 2021. Can Allotment Gardens (AGs) Be Considered an Example of Nature-Based Solutions (NBS) Based on the Use of Historical Green Infrastructure? Sustainability 13(2), 835. DOI:10.3390/su13020835

Sun, W. J., Lu, G. Y., Ye, C., Chen, S. W., Hou, Y., Wang, D. W., Wang, L. B., Oeser, M. 2018. The State of the Art: Application of Green Technology in Sustainable Pavement. Advances in Materials Science and Engineering 2018, 1-19. DOI:10.1155/2018/9760464

Szewrański, S., Chruściński, J., van Hoof, J., Kazak, J. K., Świąder, M., Tokarczyk-Dorociak, K., Żmuda, R. 2018. A Location Intelligence System for the Assessment of Pluvial Flooding Risk and the Identification of Storm Water Pollutant Sources from Roads in Suburbanised Areas. Water 10(6). DOI:10.3390/w10060746

Vacek, P., Struhala, K., Matejka, L. 2017. Life-cycle study on semi intensive green roofs. Journal of Cleaner Production 154, 203-213. DOI:10.1016/j. jclepro.2017.03.188

Van de Wouw, P. M. F., Ros, E. J. M., Brouwers, H. J. H. 2017. Precipitation collection and evapo(transpi) ration of living wall systems: A comparative study between a panel system and a planter box system. Building and Environment 126, 221-237. DOI:10.1016/j.buildenv.2017.10.002

Versini, P. A., Kotelnikova, N., Poulhes, A., Tchiguirinskaia, I., Schertzer, D., Leurent, F. 2018. A distributed modelling approach to assess the use of Blue and Green Infrastructures to fulfil stormwater management requirements. Landscape and Urban Planning 173, 60-63. DOI:10.1016/j.landurbplan.2018.02.001

Voskamp, I. M., Van de Ven, F. H. M. 2015. Planning support system for climate adaptation: Composing effective sets of blue-green measures to reduce urban vulnerability to extreme weather events. Building and Environment 83, 159-167. DOI:10.1016/j.buildenv.2014.07.018
Wałęga, A., Radecki-Pawlik, A., Kaczor, G. 2013. Naturalne sposoby zagospodarowania wód opadowych (Natural methods of rainwater management). Wydawnictwo Uniwersytetu Rolniczego w Krakowie, Kraków.

Winer, R. 2000. National Pollutant Removal Performance Database for Stormwater Treatment Practices- 2nd Edition. Center for Watershed Protection, Ellicott City.

Xiao, Y., Watson, M. 2019. Guidance on Conducting a Systematic Literature Review. Journal of Planning Education and Research 39(1), 93-112. DOI:10.1177/0739456X17723971

Xing, Y. G., Jones, P. 2019. In-situ monitoring of energetic and hydrological performance of a semi-intensive green roof and a white roof during a heatwave event in the UK, Indoor and Built Environment. DOI:10.1177/1420326×19887218

Yang, H., Florence, D. C., McCoy, E. L., Dick, W. A., Grewal, P. S. 2009. Design and hydraulic characteristics of a field-scale bi-phasic bioretention rain garden system for storm water management. Water Science and Technology 59(9), 1863-1872. DOI:10.2166/wst.2009.186

Yuan, J., Dunnett, N. 2018. Plant selection for rain gardens: Response to simulated cyclical flooding of 15 perennial species. Urban Forestry \& Urban Greening 35, 57-65. DOI:10.1016/j. ufug.2018.08.005

Yuan, J., Dunnett, N., Stovin, V. 2017. The influence of vegetation on rain garden hydrological performance. Urban Water Journal 14(10), 10831089. DOI:10.1080/1573062x.2017.1363251

Zevenbergen, C., Cashman, A., Evelpidou, N., Pasche, E., Garvin, S., Ashley, R. 2011. Urban flood management. CRC Press, London.

Zhang, L. Y., Oyake, Y., Morimoto, Y., Niwa, H., Shibata, S. 2019a. Rainwater storage/infiltration function of rain gardens for management of urban storm runoff in Japan. Landscape and Ecological Engineering 15(4), 421-435. DOI:10.1007/s11355019-00391-w

Zhang, X., Chen, N. C., Sheng, H., Ip, C., Yang, L., Chen, Y., Sang, Z., Tadesse, T., Lim, T. P. Y., 
Rajabifard, A., Bueti, C., Zeng, L. L., Wardlow, B., Wang, S., Tang, S. Y., Xiong, Z., Li, D., Niyogi, D. 2019b. Urban drought challenge to 2030 sustainable development goals. Science of the Total Environment 693, 11. DOI:10.1007/s11355019-00391-w

Zou, S. Z., Zhu, Y. R., Wei, C. J., Tao, B. H. 2018. Discussions on the Design of the Pool Landscape in the Rain Garden Construction. IOP Conference Series: Materials Science and Engineering 322, 052031. DOI:10.1088/1757-899x/322/5/052031 